\title{
HOCHEL, Marian - PAVLÍKOVÁ, Marta: Zrcadlo moci : Pilíře moci Na- poleona Bonaparta ve vizuálním umění. Praha : Národní památkový ústav, 2018. $328 \mathrm{~s}$. ISBN 978-80-7480-115-0
}

\section{DOI: https://doi.org/10.24040/ahn.2020.23.02.253-258}

V stredoeurópskom historickom bádaní v posledných rokoch stúpa záujem o interdisciplinárny výskum vzájomných vzt’ahov medzi politickými (alebo aj sociálnymi) elitami a jednotlivými formami umenia, najmä $v$ rovine reprezentácie ich postavenia a moci. $V$ centre pozornosti kultúrnych historikov je predovšetkým využívanie umenia pre politické ciele, zvlášt' vytváraním apoteóznych umeleckých diel a médií (ako je napr. film). Hoci v tejto oblasti bádania prevažujú diela zamerané na charakter, postavenie a úlohy umenia v totalitných režimoch 20 . storočia, objavujú sa aj práce, ktoré analyzujú mocensko-politické zásahy do umeleckej tvorby v starších obdobiach dejín. Zaujímavé je najmä skúmanie zásahov politickej elity do umeleckej tvorby, prípadne jej priame ovplyvňovanie prostredníctvom objednávok. Sloboda tvorby bola totiž v minulosti často len chimérickou predstavou alebo túžbou, ked'že umelci sa z existenčných dôvodov museli podriadit' požiadavkám, a niekedy aj priamej kontrole vládnucich elít. $V$ ranom novoveku umenie $v$ jeho rôznych formách slúžilo hlavne katolíckej cirkvi na šírenie jej učenia, vyhlasovaného za jediné pravé a Bohom vyvolené, svetská moc zase využívala moc umenia pre potreby vytvárania pozitívneho obrazu panovníka alebo kolektívnej vlády (napr. v talianskych mestských republikách).

Je potešitel'né, že kultúrni historici a kunsthistorici zo Slovenska alebo Čiech sa v sledovaní prepojenia politickej moci a umenia neupínajú len na domáci priestor, ale čoraz častejšie skúmajú túto problematiku v historickom vývoji iných krajín. Príkladom je aj jeden z najnovších knižných prírastkov v tejto oblasti výskumu, venovaný analýze vzt'ahu umenia a vlády Napoleona Bonaparta. Ide o monografiu s názvom $\mathrm{Zr}$ cadlo moci : pilíre moci Napoleona Bonaparta ve vizuálním umění, ktorá je dielom dvojice autorov: historika Mariana Hochela, ktorý pôsobí ako odborný asistent na Ústave historických vied Sliezskej univerzity v Opave, a Marty Pavlíkovej, odbornej pracovníčky územného pracoviska Národného pamiatkového úradu v Ústí nad Labem. Marian Hochel sa vo vedecko-pedagogickom pôsobení dlhodobo venuje novovekým dejinám so špecializáciou na vládu Napoleona I. (v rokoch 1799/1804 - 1814/1815). V praktickom výskume sa venuje hlavne interpretácii umenia klasicizmu a empíru, vládnej symbolike cisára Napoleona Bonaparta a reflexii jeho osobnosti v umeleckých dielach (tzv. napoleoniká). V posledných rokoch 
systematicky pracuje na súpise napoleoník v mobiliárnych fondoch českých hradov a zámkov. Prvým publikačným výstupom z tohto dlhodobého projektu bola monografia Třináctá komnata Napoleonova : obraz Napoleona Bonaparta v mobiliárních fondech Národního památkového ústavu (Praha : Národní památkový ústav, 2017), ktorá bola v podstate komentovaným katalógom napoleoník, nachádzajúcich sa v zbierkach pod správou českého Národného pamiatkového ústavu (a zároveň rozšíreným katalógom k rovnomennej výstave, ktorá sa konala na zámku Duchcov v roku 2013). Autorkou kvalitných fotografií popisovaných napoleoník bola Marta Pavlíková, ktorá spolupracuje s M. Hochelom pri katalogizácii. Zohrané autorské duo pripravilo v roku 2018 k vydaniu druhú publikáciu, ktorá je venovaná analýze vzt’ahu medzi politickou mocou a umením $v$ čase vlády Napoleona I.

Monografia Zrcadlo moci : pilíre moci Napoleona Bonaparta ve vizuálním umění sa skladá z dvoch častí. Prvú polovicu tvorí sedem esejistických textov, v ktorých M. Hochel (je autorom celej textovej časti) približuje rôzne aspekty spojené s umeleckou tvorbou za vlády Napoleona Bonaparta, vzt'ah cisára k rôznym formám umenia, ale najmä jeho postoj $\mathrm{k}$ (re)prezentácii jeho moci a úspechov. V druhej polovici textu akoby sa autor vracal ku konceptu svojej predchádzajúcej knihy: prezentuje v nej umelecké predmety, ktoré zobrazujú osobnost' Napoleona Bonaparta, oslavujú jeho vojenské alebo politické úspechy alebo len vznikli na základe jeho objednávky. Všetky predmety sa, samozrejme, nachádzajú v mobiliárnych fondoch českých zámkov. Hoci aj tu je pri každom umeleckom predmete uvedený jeho krátky opis, väčšiu čast' textu tvorí erudované priblíženie jeho vzniku, účelu a vysvetlenie použitého námetu alebo symboliky. Každé opisované umelecké dielo je vyobrazené na kvalitnej celostranovej farebnej reprodukcii.

V prvých siedmych kapitolách autor z rôznych uhlov popisuje vzt'ah Napoleona Bonaparta k umeniu (či rôznym formám umenia), ktorý bol vyjadrený nielen priamymi objednávkami umeleckých diel, budovaním súkromných umeleckých zbierok na cisárskych sídlach (i prvej verejnej galérie v paláci Louvre), ale aj podporou pamiatkovej ochrany významných stavieb a pamätníkov. Zaujímavé je aj použitie ideového konceptu z dvoch zdanlivo celkom odlišných diel: z Vladára od Niccola Machiavelliho a z knihy Vôl'a k moci od nemeckého filozofa Friedricha Nietzscheho. Hlavné idey oboch diel sa v podobe početných citátov a prirovnaní vinú celým textom knihy a hrajú dôležitú úlohu v úvahách a Hochelových argumentoch. Machiavelliho predstava panovníka, ktorý využíva všetky prostriedky na získanie a upevnenie osobnej vlády, ako aj Nietzscheho myšlienky o l'udskej vôli ako dominujúcom faktore v konaní výrazných postáv l'udských dejín, sa totiž skvele hodia aj na osobu Napoleona Bonaparta. 
V rozsiahlom úvode (1. kapitola na s. 7 - 34) je čitatel’om predstavená štruktúra a obsah knihy, ako aj spomínaný interpretačný koncept diela (založený na myšlienkach Machiavelliho a Nietzscheho). Autor predstavuje jednotlivé ciele publikácie, ktoré hned’ dáva do súvisu s umeleckohistorickým bádaním o napoleonskej epoche v zahraničí (najmä vo Francúzsku). Autor v knihe poukazuje na javy a súvislosti, ktoré ovplyvňovali umeleckú tvorbu v období prvého cisárstva, približuje systém objednávok a financovania výtvarných diel a úžitkových predmetov, ale dotýka sa aj problematiky ochrany a prezentácie umeleckých diel, či zbierania napoleoník súkromnými zberatel'mi (často zo šl'achtického prostredia). Najväčšiu pozornost' venuje nosnej téme knihy, ktorou je vytváranie historickej pamäti v spojitosti s osobou Napoleona Bonaparta. Autor v kapitole venoval priestor aj premenám inštalácie a prezentácie umeleckých predmetov v minulosti a v súčasnosti, a to hlavne v prostredí českých zámkov i zahraničných (najmä francúzskych) múzeí.

Po úvodnej časti nasleduje šest' samostatných kapitol, ktoré sú zamerané na analýzu a interpretáciu umeleckej tvorby vo Francúzsku na prelome 18. a 19. storočia. V kapitole s názvom „Zrození vůle k moci : Nietzscheho Napoleon" sa autor pokúsil o filozoficko-historické zdôvodnenie Napoleonovho úspechu, pričom si pomáhal hodnoteniami jeho osobnosti dobovými súčasníkmi. Z nich vyplýva, že úspešného vojvodcu, a neskôr aj politika skutočne poháňala dominujúca túžba po presadení sa, ktorú môžeme vnímat” aj ako „vôlu k moci“. Presadenie sa, získanie významného postavenia a moci samotný Napoleon vnímal až fatalisticky, čo dosvedčuje aj jeho výrok: „Som povolaný, aby som zmenil tvár sveta, aspoň som o tom presvedčený. S touto myšlienkou sa možno spája akási predstava osudovosti, ktorú však nezavrhujem. Dokonca v ňu verím, a táto viera je zdrojom môjho úspechu." (Z listu bratovi Jozefovi Bonapartovi; citované na s. 140). Koncepcia „vôle k moci“ sa objavuje aj v d'alších kapitolách pri analýze ovplyvňovania umeleckej tvorby Napoleonom a/alebo jeho vládnym aparátom.

$\mathrm{V}$ nasledujúcej kapitole s názvom „Vưlí k moci a ke slávě : umění a umělci ve službách Napoleona Bonaparta“ je už pozornost' venovaná najvýznamnejším maliarom a sochárom, ktorí boli v cisárových službách, prípadne aj teoretikom umenia a kustódom múzeí, ktoré boli zriadené Napoleonom. Na podklade opísaných objednávok umeleckých diel, bud' priamo ním alebo z prostredia jeho dvora, si čitatel' vytvorí predstavu o Napoleonovom vzt'ahu k umeniu, a najmä o jeho pragmatickom chápaní úloh umeleckej tvorby. Je evidentné, že cisár a jeho poradný zbor pre otázky umenia cielene vytvárali pozitívny obraz o jeho činoch a živote, ktorý mal posilňovat' jednak legitimitu jeho moci, a tiež podporu verejnosti. Najmä jeho nesporné vojenské úspechy boli spodobené v početných mal'bách a sochách, alebo aj v monumentálnych stavbách, ktoré 
mali byt' trvalou spomienkou na jeho vít’azné vojny. Zaujímavý je napr. meniaci sa postoj Napoleona k stavbe vít'azných oblúkov, na ktorých mali byt' sochársky spodobené jeho početné vít’azstvá (s. 48 - 49). Čitatel'a možno prekvapí stručné predstavenie cisárovho záujmu o ochranu historických pamiatok a jeho priamy vklad k vytvoreniu verejnosti prístupnej galérie v král'ovskom paláci Louvre.

Obsahom štvrtej, rozsahom stručnej (len tri strany textu) kapitoly s názvom „Vůle k moci : mezi krásným a užitým uměním“ je kratšie zamyslenie sa nad Napoleonovým vzt'ahom ku krásnym umeniam (najmä maliarstvo, sochárstvo a architektúra) a k úžitkovému umeniu. Autor poukazuje na fakt, že panovník do istej miery stieral hranice medzi nimi, ked'že aj diela úžitkového umenia vnímal ako súčast' esteticky vyššieho umenia. Samozrejme, obom druhom priradil pragmatické ciele v zmysle pozitívnej prezentácie jeho osobnosti a apoteózy jeho vlády. Hoci pre tieto ciele Napoleon preferoval maliarske a sochárske diela, na jeho príkaz boli vytvárané aj početné umelecké diela úžitkovej povahy (luxusný nábytok, porcelánové a sklenené servisné súpravy, stolové hodiny, koberce a tapisérie, šperky a luxusné či ceremoniálne zbrane), ktoré slúžili hlavne ako výbava interiéru cisárskych rezidencií.

V piatej kapitole „Vůle k moci okem mecenáše a sběratele“ je nosnou témou kultúrny mecenát počas Napoleonovej vlády. Autor nepribližuje len systém fungovanie zákaziek z prostredia cisárskeho dvora, ale všíma si aj organizovanie umeleckých konkurzov (sút’aží) či tradičného Salónu maliarstva a sochárstva, teda každoročne konanej výstavy nových umeleckých diel od významných tvorcov. Práve fenoménu Salónu je v kapitole venovaný značný priestor. Za král'ovského režimu bol Salón organizovaný pravidelne v priestoroch paláca Louvre, ale vystavovat' svoje diela mohli len umelci sústredení v Král'ovskej akadémii maliarstva a sochárstva (Académie royale de peinture et de sculpture, založená v roku 1648). Počas francúzskej revolúcie bol prístup na Salón povolený aj neakademickým umelcom a Napoleon ho v roku 1802 nanovo zreorganizoval. V kapitole sú uvedené niektoré diela prezentované na Salónoch počas trvania 1. cisárstva, pričom z uvedených diel je evidentné, že vel'ký ohlas vzbudili najmä práce zobrazujúce činy Napoleona, ktoré vytvárali najlepší umelci tej doby (ako napr. François-Pascal-Simon Gérard, AnneLouis Girodet, Antoine-Jean Gros alebo Jean-Louis David). V texte kapitoly autor približuje aj systém udel'ovania odmien za najlepšie ohodnotené umelecké diela, prípadne aj odmeňovanie umelcov radmi a šl'achtickými titulmi (umelci mohli napríklad získat' ním založený Rad čestnej légie). Pozornost' je venovaná aj d’alším formám štátnych zákaziek, ktoré väčšinou zadával a kontroloval generálny riaditel' múzeí Dominique-Vivant Denon. V kapitole sa nachádza aj obšírny popis štátnych zákaziek na 
luxusné predmety, spadajúce do kategórie úžitkového umenia (na s. 97 - 102), ktoré by podl'a našej mienky bolo vhodnejšie zasadit' do textu predchádzajúcej, rozsahom príliš skromnej kapitoly. Záver tvorí pojednanie o zbieraní umeleckých diel prvej Napoleonovej manželky cisárovnej Jozefíny (Joséphine de Beauharnais), ako aj členmi širokej Napoleonovej rodiny.

V šiestej kapitole „Vůle k moci v historizaci“ je pozornost' venovaná vzt’ahu Napoleona Bonaparta k histórii a k literatúre, ale najmä historizácii Napoleonovho obrazu. Tá spočívala najmä v prirovnávaní jeho osoby k významným postavám dejín, predovšetkým k osobnostiam antiky (ako bol Gaius Iulius Caesar alebo Octavianus Augustus). Autor tiež podčiarkuje výrazný vplyv antického rímskeho umenia na kreovanie originálneho výtvarného štýlu Napoleonovej doby, ktorý dostal meno empír. V texte kapitoly sú použité početné dobové hodnotenia Napoleona a prirovnania jeho osoby k iným historickým postavám.

Siedma kapitola má názov „Napoleon za zrcadlem“ a nosnou témou v nej je úvaha o obraze, ktorý o sebe mal - a ktorý aktívne (spolu)vytváral - samotný Napoleon. Je nesporným faktom, že tento obraz bol vel'mi ovplyvnený jeho rastúcimi ambíciami a mocou, ktorú si dokázal získat' a udržat' takmer 15 rokov vd'aka svojej odvahe, schopnostiam, úsiliu, ale azda aj značnej dávke št'astia. Napoleon si uvedomoval, že pozitívny obraz o ňom a jeho činoch je potrebné ciel'avedome vytvárat' a udržiavat', pretože potreboval podporu verejnosti pre svoje zámery, ktoré si žiadali značné finančné prostriedky, a tiež l'udské zdroje. V podstate tak bol inšpirátorom propagandy, do služieb ktorej bolo od začiatku jeho vlády zapojené aj umenie. V súvislosti s charakteristikou Napoleonovej osobnosti autor cituje viaceré jeho výroky, ale tiež hodnotenia jeho súčasníkov (napr. Madame de Staël), a napokon aj stručné zhrnutia o Napoleonovi z diel novodobých historikov (J. Tulard, F. Monnier, F. Furet, J.-O. Boudon).

Takmer polovicu rozsahu knihy tvorí ôsma kapitola „Napoleonika mezi mýtem a historickou pamětí“. Tu sa charakter diela opät’ mení na akýsi komentovaný katalóg umeleckých predmetov s napoleonskou tematikou, ktoré sú zastúpené v mobiliárnych fondoch českých zámkov a hradov (ako napr. Kynžvart, Sychrov alebo Konopiště). Texty pozostávajú z opisu konkrétneho predmetu, uvedenia jeho autora a vysvetlenia jednotlivých umelecko-symbolických detailov. Obsahom a štýlom je text vel'mi podobný textu autorovej prvej monografie o napoleonikách s názvom Třináctá komnata Napoleonova. Autor v kapitole analyzuje viac ako šest'desiat predmetov od pamätných medailí, diel úžitkového umenia ako sú hodiny, servisné súpravy, alebo šachové figúrky až po obrazy a grafické listy, na ktorých je zobrazený Napoleon. Všetky diela sú nielen 
detailne opísané, ale je priblížený aj kontext ich vzniku a viac či menej skrytá napoleonská symbolika.

Textovú čast' knihy uzatvára záver, v ktorom autor stručne zhrnul ciele a prínos monografie. V niekol'kých odstavcoch zosumarizoval charakter umenia v čase vlády Napoleona Bonaparta a jeho chápanie politicko-ideologickej úlohy, ktoré malo plnit'. Podl'a vlastných slov autora má byt' jeho dielo „manuálom pre pochopenie kultúrnej politiky Napoleonovho režimu v oblasti vizuálneho umenia a jeho reálnych dopadov v oblasti kultúrneho dedičstva“" (s. 300). Po prečítaní celého diela môžeme potvrdit', že M. Hochel vytvoril manuál nielen informačne hodnotný, ale aj brilantne napísaný a nádherne ilustrovaný. Text je ešte doplnený o prílohu so štyrmi dobovými prameňmi. Ide o úryvok z ceremoniálneho protokolu o korunovácii Napoleona Bonaparta a jeho manželky Jozefíny, o výt'ah z tzv. „Cisárskeho katechizmu“ z roku 1806, a napokon o dva listy z roku 1810, ktoré sa viažu k sobášu Napoleona s dcérou rakúskeho cisára Františka I. Habsburského, arcivojvodkyňou Máriou Lujzou. Pramene sú uvedené bilingválne (česky a francúzsky). Knihu uzatvára desat'stranový zoznam použitej literatúry a francúzsko-anglické zhrnutie.

Monografia Zrcadlo moci : pilíre moci Napoleona Bonaparta ve vizuálním umění je významným vkladom do problematiky skúmania vzájomného ovplyvňovania politických dejín a umeleckej tvorby v období vlády Napoleona Bonaparta. Erudovaný pohl'ad na vytváranie politicky motivovanej umeleckej reflexie cisára a množstvo čitatel'sky zaujímavých detailov pri opise napoleoník uspokoja každého čitatel'a, ktorý má záujem dozvediet' sa viac o osobnosti Napoleona Bonaparta, o jeho vzt'ahu k umeniu, ako aj o kultúrnej politike počas jeho vlády.

Patrik Kunec 